\title{
PENGARUH MEDIA DAKOTA TERHADAP KEMAMPUAN BERPIKIR KRITIS MATERI KPK FPB KELAS IV SDN 01 GEMUHBLANTEN
}

\author{
Winda Putri Ardhia ${ }^{1,}$ Dwi Prasetiyawati ${ }^{2}$, Sunan Baedowi ${ }^{3}$ \\ PGSD, FIP, Universitas PGRI Semarang \\ email:windaputri150@gmail.com
}

\begin{abstract}
The purpose of this study was to determine the effect of dakota media on students' critical thinking skills in KPK and FPB material. This type of research is quantitative with the research design of One-Group Pretest-Posttest Design. The population were all fourth grade students of SDN 01 Gemuhblanten. The sample taken was 19 fourth grade students. The data in this study were obtained through tests, interviews, observations, and documentation. The results of hypothesis testing on students' critical thinking abilities show that $t_{\text {count }} 19.851$ and $t_{\text {table }} 2.086$ with a significancy level of 5\%. Because $t_{\text {count }}>t_{\text {table }}$ is 19.851> 2.086, then $H_{a}$ is accepted, that is, dacota media has an effect on students' critical thinking abilities.
\end{abstract}

Keywords: dakota media, critical thinking ability

\begin{abstract}
Abstrak
Tujuan penelitian ini adalah untuk mengetahui pengaruh media dakota terhadap kemampuan berpikir kritis siswa pada materi KPK dan FPB. Jenis penelitian ini adalah kuantitatif dengan desain penelitian One-Group Pretest-Posttest Design. Populasi dalam penelitian adalah seluruh siswa kelas IV SDN 01 Gemuhblanten. Sampel yang diambil adalah 19 siswa kelas IV. Data dalam penelitian ini diperoleh melalui tes, wawancara, observasi, dan dokumentasi. Hasil pengujian hipotesis pada kemampuan berpikir kritis siswa menunjukan bahwa $t_{\text {hitung }}$ 19,851 dan $t_{\text {tabel }} 2,086$ dengan taraf signifikansi 5\%. Karena $t_{\text {hitung }}>t_{\text {tabel }}$ yaitu 19,851 > 2,086 maka $H_{a}$ diterima artinya, media dakota berpengaruh terhadap kemampuan berpikir kritis siswa .
\end{abstract}

Kata Kunci: media dakota, kemampuan berpikir kritis 


\section{PENDAHULUAN}

Pembelajaran yang berkualitas menentukan kualitas peserta didik. Dalam dunia pendidikan khususnya di sekolah diperlukan peserta didik yang aktif untuk bisa berpikir kritis dalam menyelesaikan persoalan matematika. Dalam proses pembelajaran matematika dianggap sulit dan susah dipahami. Menurut Oktiana Dwi Putra Herawati, Rusdy Siroj, dan Djahir Basir (2010:71) menyatakan bahwa dalam mempelajari matematika siswa harus memahami konsep matematika, maka konsep matematika harus ditanamkan sejak dini yaitu sejak anak duduk dibangku sekolah dasar agar menjadi bekal untuk pendidikan selanjutnya. Oleh karena itu wajar jika matematika tidak mudah dipahami oleh kebanyakan siswa sekolah dasar, terutama dalam penyampaian konsep guru hanya menerangkan tanpa alat peraga atau media yang menarik. Berdasarkan karakteristik siswa SD yang masih membutuhkan benda-benda konkret maka diperlukan alat peraga untuk mempermudah siswa memahami materi pembelajaran. Media pembelajaran merupakan salah satu cara memberikan gambaran nyata tentang materi yang diberikan, sekaligus alat pendukung untuk mempermudah guru dalam mengajar. Fisher (2009:7) menyatakan bahwa untuk meningkatkan kemampuan berpikir kritis siswa yaitu mengenal masalah dan menemukan cara-cara yang dapat dipakai untuk menangani masalah tersebut. Sedangkan menurut Kuswana (2012:198) untuk menemukan cara-cara yang dipakai dalam menangani masalah, mengidentidikasi fokus masalah dapat membantu menciptakan suasana berpikir bagi peserta didik. Keberhasilan dalam proses pembelajaran sangat ditentukan oleh keadaan proses pembelajaran yang diterapkan.

Setelah dilakukan wawancara terhadap guru kelas IV SDN 01 Gemuhblanten Kendal disimpulkan bahwa permasalahan yang dihadapi terkait mata pelajaran matematika terdapat $57 \%$ siswa yang mendapat nilai di bawah Kriteria Ketuntasan Minimal (KKM) yaitu 65. Hal tersebut dikarenakan rata-rata siswa belum menguasai sepenuhnya materi yang disampaikan terutama materi 
KPK dan FPB. Faktor-faktor yang mempengaruhi hal tersebut adalah siswa kurang memahami perkalian dan pembagian, hanya $43 \%$ siswa yang mampu berpikir kritis, pengajar belum bervariasi dalam menggunakan media pembelajaran dan keterbatasan penggunaan media pembelajaran. Pada pembelajaran matematika materi KPK dan FPB di kelas IV seharusnya siswa diberikan kesempatan belajar menggunakan media yang menarik agar dapat menciptakan suasana belajar yang menyenangkan. Salah satu upaya yang dilakukan guru untuk meningkatkan kemampuan berpikir kritis siswa yaitu dengan menggunakan media pembelajaran yang lebih baik agar hasil belajar dapat meningkat.

Bersumber pendapat diatas maka penggunaan media dapat meningkatkan kemampuan berpikir kritis siswa, media tersebut dapat menjadi salah satu cara untuk menyampaikan pembelajaran KPK dan FPB. Sehingga diberikan solusi untuk menggunakan media Dakon Matematika (DAKOTA) pada mata pelajaran matematika materi KPK dan FPB kelas IV SDN 01 Gemuhblanten
Kendal. Media dakota merupakan media yang terbuat dari triplek sepanjang sekitar $100 \mathrm{~cm}$ dengan lebar 25 cm. Wadah dakon menggunakan wadah agar-agar yang berukuran kecil yang telah dilengkapi dengan nomor 1-30 dan akan diisi dengan manik-manik dua warna.

Hal ini juga sesuai dengan hasil penelitian Aspriliana (2018) yang menyatakan bahwa media dakon bilangan dapat meningkatkan hasil belajar siswa materi KPK dan FPB. Hal ini dibuktikan dengan perhitungan uji-t data posttest kelas eksperimen dan kelas kontrol menggunakan rumus polled varians, diperoleh $t_{\text {hitung }}$ sebesar 2,549 dan $t_{\text {tabel }}(\alpha=5 \%)$ sebesar 1,670133. Karena $t_{\text {hitung }}(2,549)>t_{\text {tabel }}$ (1,670133). Dengan demikian maka $H_{a}$ diterima. Jadi, disimpulkan ada perbedaan pada kelas eksperimen dan kelas kontrol.

\section{METODE PENELITIAN}

Metode penelitian yang digunakan adalah metode kuantitatif dengan fokus penelitian menggunakan satu kelas eksperimen. Menggunakan desain pre- 
experimental design dengan jenis One-Group Pretest-Posttest. Subjek penelitian yang akan digunakan dengan 1 sampel subjek penelitian. Subjek yang diteliti adalah siswa kelas IV SDN 01 Gemuhblanten yang berjumlah 19 siswa.

Pada penelitian ini menggunakan sampel non probability sampling dengan teknik sampling jenuh, sehingga semua anggota populasi digunakan (Sugiyono, 2016:117). Teknik pengumpulan data dalam penelitian ini yaitu tes dan non tes. Dalam metode tes ini menggunakan butir tes uraian, bentuk tes uraian digunakan untuk mengukur seberapa besar peningkatan kemampuan berpikir kritis siswa. Sedangkan untuk non tes menggunakan teknik wawancara, observasi, dan dokumentasi.

\section{HASIL DAN PEMBAHASAN}

Penelitian yang dilakukan diperoleh data awal dari hasil nilai pretest, dan data akhir yang diperoleh dari hasil posttest. Dari data yang diperoleh dari pretest materi KPK dan FPB, indikator kemampuan berpikir kritis diperoleh data seperti pada tabel berikut ini:

Tabel 1. Rekapitulasi nilai kemampuan berpikir kritis pretest dan posttest

\begin{tabular}{ccc}
\hline Keterangan & Pretest & Posttest \\
\hline $\begin{array}{c}\text { Nilai } \\
\text { tertinggi }\end{array}$ & 75 & 70 \\
\hline $\begin{array}{c}\text { Nilai } \\
\text { terendah }\end{array}$ & 25 & 95 \\
\hline Tuntas & 3 & 19 \\
\hline Tidak tuntas & 16 & 0 \\
\hline Rara-rata & 45 & 84 \\
\hline
\end{tabular}

Berdasarkan tabel 1 dapat dilihat perolehan rata-rata nilai pretest 45 dan posttest 84 menghasilkan selisih 39. Pada hasil pretest nilai terendah 25 dan nilai tertinggi 75 . Pada nilai tuntas pretest terdapat 3 anak saja, sedangkan nilai posttest keseluruhan siswa nilainya tuntas. Perbedaan nilai kemampuan berpikir kritis siswa dapat dilakukan menggunakan uji statistik yang sesuai terhadap data hasil belajar. Data hasil belajar siswa yang diperoleh dari nilai pretest dan posttest diperoleh dengan menghitung menggunakan rumus parametrik. Perhitungan tersebut dimulai dengan menghitung uji normalitas, uji t-test, dan uji ketuntasan belajar.

Pemerolehan data uji normalitas dari skor pretest diperoleh 
menggunakan uji Liliefors dengan taraf signifikansi 5\% dengan kriteria $\mathrm{L}_{\text {hitung }}<\mathrm{L}_{\text {tabel }}$ maka populasi berdistribusi normal. Perhitungan uji normalitas sebelum diberikan perlakuan diperoleh rata-rata 45 . Dengan $\mathrm{L}_{\text {hitung }}<\mathrm{L}_{\text {tabel }}$ yaitu $0,172<$ 0,195 pada signifikasi 5\% dengan $\mathrm{N}$ 19, maka $\mathrm{H}_{\mathrm{o}}$ diterima. Pemerolehan data uji normalitas setelah diberikan perlakuan diperoleh rata-rata 84 . Dengan $\mathrm{L}_{\text {hitung }}$ 0,141, dan $\mathrm{L}_{\text {tabel }}$ 0,195. Karena $\mathrm{L}_{\text {hitung }}<\mathrm{L}_{\text {tabel }}$ maka data pemerolehan posttest berdistribusi normal.

Pemerolehan data ketuntasan belajar individu yaitu siswa dikatakan tuntas apabila mampu mencapai tujuan pembelajaran minimal $70 \%$. Berdasarkan data hasil pretest hanya ada 3 siswa yang tuntas. Untuk hasil posttest mengalami peningkatan yaitu sebanyak 19 siswa dinyatakan tuntas. Pemerolehan data ketuntasan belajar klasikal jika lebih dari $85 \%$ siswa tuntas belajar. Berdasarkan hasil penelitian hasil ketuntasan belajar klasikal untuk pretest hanya ada 16\%, untuk nilai posttest meningkat menjadi $100 \%$
Berdasarkan hasil perhitungan uji-t data pretest dan posttest diperoleh $t_{\text {hitung }}$ sebesar 19,851 dan $t_{\text {tabel }}$ dengan $d b=N-1=19-1=18$, dengan taraf signifikansi 5\% sebesar 2,086. Karena $t_{\text {hitung }}>t_{\text {tabel }}$ yaitu 19,851 > 2,086 maka $\mathrm{H}_{\mathrm{o}}$ ditolak dan $\mathrm{H}_{\mathrm{a}}$ diterima. Sehingga dapat dikatakan bahwa media dakota berpengaruh terhadap kemampuan berpikir kritis siswa kelas IV SDN 01 Gemuhblanten.

Berdasarkan hasil penelitian yang telah dilakukan, siswa dapat memahami konsep KPK dan FPB dengan mudah karena adanya media dakota dalam proses belajar mengajar. Siswa menjadi lebih mudah memahami, menghitung, dan memperjelas konsep langkah-langkah menentukan KPK dan FPB. Sehingga tujuan pembelajaran dapat tercapai dan dapat meningkatkan kemampuan berpikir kritis siswa.

Pada saat pembelajaran menggunakan media dakota materi menentukan kelipatan persekutuan dan KPK, siswa merasa tertarik mendengarkan pembelajaran karena tidak menghafal perkalian dapat dengan mudah menentukan kelipatan 
Jurnal Sinektik

Volume 2 Nomor 2, Edisi Desember 2019

Prodi PGSD Universitas Slamet Riyadi

ISSN 2620-6560 (print) ISSN 2620-746X (online)

suatu bilangan dengan cara

menghitung manik-manik

Penggunaan media dakota juga mempermudah siswa dalam

menghitung faktor persekutuan dan

FPB. Dengan adanya media dakota siswa dapat mempersempit hasil pembagian dengan jelas. misalnya siswa ingin mencari faktor dari 18. Pertama-tama siswa memasukkan manik-manik kedalam angka 1 dan 18. Alasannya karena $18: 1=18$. Selanjutnya siswa menghitung kembali apakah 18 bisa dibagi 2, jika bisa maka siswa memasukkan manikmanik ke dalam 2 dan 9 karena $18: 2$ =9. Dan seterusnya sampai proses pencarian terhenti jika titik awal sudah bertemu dengan titik akhir. Dengan proses demikian penggunaan dakota dinilai dapat mempermudah menentukan faktor persekutuan dan FPB.

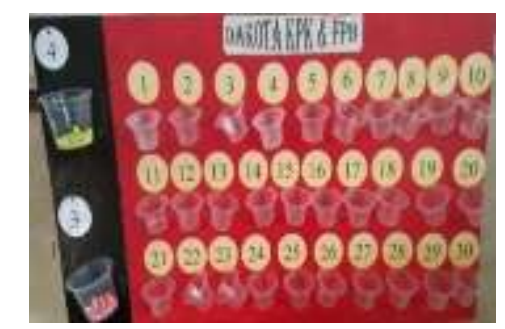

Gambar 1. Media DAKOTA (Dakon Matematika)
Penggunaan media dakota pada $\begin{array}{llll}\text { siswa kelas IV SDN } & 01\end{array}$ Gemuhblanten sangat membantu siswa dalam memahami materi KPK dan FPB, mulai dari konsep hingga menghitung hasil KPK dan FPB dua bilangan. Dibuktikan dengan peningkatan presentase hasil pretest dan posttest siswa naik, dan hasil posttest tidak ada siswa yang nilainya dibawah KKM. Peningkatan tersebut terjadi dikarenakan dalam pembelajaran menggunakan media dakota siswa berperan aktif menggunakan media dakota dengan bantuan guru. Siswa juga turut serta menghitung KPK dan FPB menggunakan media dakota sehingga siswa lebih antusias mengikuti pembelajaran, dengan adanya media dakota menjadikan materi lebih mudah untuk disampaikan. Karena siswa belajar sambil bermain, sehingga minat belajar siswa tinggi dan informasi atau pengetahuan terkait materi KPK dan FPB dapat diterima dan dipahami siswa dengan baik. Hal ini sejalan dengan pendapat Sundayana (2015:4) mengemukakan media meupakan dengan demikian media merupakan wahana penyalur 
informasi belajar atau penyalur pesan. Selain itu dengan adanya media dakota siswa terlihat lebih aktif dan terampil dalam memasang manikmanik sesuai dengan soal yang diberikan. Beberapa siswa terlihat lebih teliti dan kritis saat berdiskusi, sejalan dengan Munadi (2013:6) media adalah segala sesuatu yang dapat menyampaikan dan menyalurkan pesan dari sumber secara terencana sehingga tercipta lingkungan belajar yang kondusif dimana penerimanya dapat melakukan proses belajar secara efisien dan efektif. Dengan media dakota berpengaruh dalam meningkatkan antusias siswa dalam mempelajari materi KPK dan FPB, sikap teliti dalam belajar sehingga siswa mampu berpikir kritis saat proses pembelajaran.

Media dakota dapat membantu pengajar lebih mudah dalam mengajarkan materi KPK dan FPB. Media dakota dalam penelitian ini difokuskan untuk meningkatkan kemampuan berpikir kritis siswa. Saat diberikan perlakuan di kelas IV SDN 01 Gemuhblanten menggunakan media dakota terdapat fakta: : (1) siswa sangat antusias terhadap pembelajaran, (2) siswa ikut berpartisipasi aktif dalam melakukan tanya jawab dengan guru, (3) siswa mampu memahami materi dengan jelas, (4) siswa aktif mencari informasi dari media dakota, (5) siswa mampu membedakan antara faktor dan kelipatan, (6) siswa mampu menghitung perkalian dan pembagian. Pelaksanaan pembelajaran dengan menggunakan media dakota ini dibuat dengan pembentukan diskusi kelompok, sehingga siswa lebih tertarik dan terjalin kerjasama yang baik antarsiswa.

\section{SIMPULAN}

Berdasarkan hasil penelitian yang didasarkan pada analisis data statistik dan kenyataan dilapangan peneliti dapat menyimpulkan bahwa dengan adanya media dakota siswa menjadi lebih semangat belajar, kemampuan berpikir kritis siswa yang tadinya dibawah KKM yaitu 65 setelah diberikan perlakuan menggunakan media dakota menjadi meningkat diatas KKM. Hal ini dibuktikan dengan hipotesis 
menggunakan uji t-test diperoleh hasil tabel dengan $\mathrm{db}=\mathrm{N}-1=19-1=18$, dan taraf signifikansi $5 \%$ sebesar 2,086. Karena $t_{\text {hitung }}>t_{\text {tabel }}$ yaitu 19,851 > 2,086 maka $\mathrm{H}_{\mathrm{o}}$ ditolak dan $\mathrm{H}_{\mathrm{a}} \quad$ diterima. Sehingga dapat dikatakan bahwa media dakota berpengaruh terhadap kemampuan berpikir kritis siswa pada materi KPK dan FPB kelas IV SDN 01 Gemuhblanten

Saran untuk penelitian selanjutnya mengenai media dakota perlu ditambahkan model agar pembelajaran berjalan semakin menarik. Kemudian, media ini sebaiknya digunakan pada kelas rendah agar dapat diketahui pengaruhnya.

\section{DAFTAR PUSTAKA}

Aspriliana, Rizka. 2018. Pengaruh Media Dakon Bilangan Terhadap Hasil Belajar FPB dan KPK Siswa SDN 34 Pontianak. Jurnal Pendidikan dan Pembelajaran Khatulistiwa. Volume 7 Nomor 3.

Fisher, Alec. 2009. Berpikir Kritis. Jakarta : Erlangga

Kuswana, Wowo Sunaryo. 2012. Taksonomi Kognitif Perkembangan Ragam Berpikir. Bandung: Rosda
Munadi, Yudhi. 2013. Media Pembelajaran: Sebuah Pedekatan Baru. Jakarta: Referensi

Oktiana Dwi Putra Herawati, Rusdy Siroj, dan Djahir Basir. 2010. Pengaruh Pembelajaran Problem Posing Terhadap Kemampuan Pemahaman Konsep Matematika Siswa Kelas XI IPA SMA Negeri 6 Palembang. Jurnal Pendidikan Matematika. Volume 4 No 1.

Sugiyono. 2016. Metode Penelitian Kualitatif, Kuantitatif, dan $R \& D$. Bandung : Alfabeta

Sundayana, Rostina. 2015. Media dan Alat Peraga dalam Pembelajaran Matematika : untuk Guru, calon Guru, Orangtua, dan Para Pecinta Matematika. Bandung : Alfabeta 